\title{
INFLUÊNCIA DA TEMPERATURA DURANTE O TRANSPORTE, NA QUALIDADE MICROBIOLÓGICA DO LEITE RECEBIDO POR UMA INDÚSTRIA DE LATICÍNIOS NO PLANALTOCATARINENSE*
}

\author{
DJENANE DOS SANTOS
}

Guiomar Pedro Bergmann (Orientador -UFRGS)

Banca Examinadora: Carla Christine Lange Jane Maria Rübensam José Maria Wiest
PUCRS

UFRGS

UFRGS

Neste estudo foi avaliada a influência da temperatura durante o transporte na qualidade microbiológica do leite. Para tanto, foram analisadas 125 amostras de leite, de diferentes produtores, transportado em tarros em temperatura ambiente e 125 amostras de leite de coleta a granel, simulada, sob refrigeração. A temperatura média durante o transporte foi de $18,35^{\circ} \mathrm{C}$ para o transporte em temperatura ambiente e $4,5^{\circ} \mathrm{C}$ para o transporte sob refrigeração. $\mathrm{O}$ tempo de transporte da propriedade até a plataforma da indústria foi de 2 horas e 30 minutos em média. Na contagem de mesófilos aeróbios a média foi de $7,27 \log _{10} \mathrm{UFC} / \mathrm{mL}$ nas amostras transportadas em temperatura ambiente; nas amostras transportadas sob refrigeração, a média foi de $6,42 \log _{10} \mathrm{UFC} / \mathrm{mL}$. A diferença entre as duas temperaturas de transporte foi de 7 vezes e estatisticamente significativa $(\mathrm{p}<0,05)$ por análise de variância e por teste t-student pareado. Para contagem de coliformes totais das amostras transportadas em temperatura ambiente a média foi de $5,07 \log _{10} \mathrm{UFC} / \mathrm{mL}$ e de $4,07 \log _{10} \mathrm{UFC} / \mathrm{mL}$ nas amostras transportadas sob refrigeração. A diferença entre as duas temperaturas de transporte foi de 10 vezes e estatisticamente significativa $(\mathrm{p}<0,05)$ por análise de variância e por teste $\mathrm{t}$-student pareado. Para psicrótrofos, nas amostras transportadas em temperatura ambiente a contagem média foi de $6,34 \log _{10} \mathrm{UFC} / \mathrm{mL}$, e nas amostras transportadas sob refrigeração, de 5,74 $\log _{10} \mathrm{UFC} / \mathrm{mL}$. A diferença entre as duas temperaturas de transporte foi de 4 vezes e estatisticamente significativa $(\mathrm{p}<0,05)$ por análise de variância e por teste t-student pareado.

Descritores: leite, temperatura de transporte, transporte em tarros, transporte a granel, mesófilos, coliformes, psicrótrofos.

Apresentada: 30 julho 2001

* Dissertação de Mestrado n.0308 (Especialidade: Inspeção de Produtos de Origem Animal). 80f. Programa Pós-Graduação em Ciências Veterinárias da Faculdade de Veterinária, Porto Alegre - UFRGS. CORRESPONDÊNCIA: D.Santos [e-mail: nane.s@zipmail.com.br]. 


\title{
INFLUENCE OF TEMPERATURE DURING THE TRANSPORT OVER THE MICROBIOLOGIC QUALITY OF THE MILK RECEIVEDBY A DAIRY INDUSTRY IN THE CATARINENSE PLATEAU**
}

\author{
DJENANE DOS SANTOS
}

Guiomar Pedro Bergmann (Adviser -UFRGS)

\begin{abstract}
Committee:
Carla Christine Lange PUCRS

Jane Maria Rübensam UFRGS

José Maria Wiest UFRGS
\end{abstract}

In this research the influence of temperature during the transport over the microbiologic quality of raw milk was evaluated. For that 125 samples of milk, from different producers, transported on ambient temperature (in cans) and 125 samples of simulated bulk milk were analyzed. The average of temperature was $18,35^{\circ} \mathrm{C}$ to canned milk and $4,5^{\circ} \mathrm{C}$ to bulk milk. The duration of transport was 2 hours and 30 minutes in average. Aerobic mesophilic had average counting of 7,27 $\log _{10} \mathrm{UFC} / \mathrm{mL}$ to canned milk and $6,42 \log _{10} \mathrm{UFC} / \mathrm{mL}$ to bulk milk. The difference between the two temperatures of transportation was of 7 fold and statistically significant $(p<0,05)$ by analysis of variance and by t-student for dependent samples. Counting of total coliforms had average of 5,07 $\log _{10} \mathrm{UFC} / \mathrm{mL}$ to canned milk and $4,07 \log _{10} \mathrm{UFC} / \mathrm{mL}$ to bulk milk. The difference between the two temperatures of transportation was of 10 fold and statistically significant $(\mathrm{p}<0,05)$ by analysis of variance and by $\mathrm{t}$ student for dependent samples. To psicrotrophs the average was $6,34 \log _{10} \mathrm{UFC} / \mathrm{mL}$ to canned milk and 5,74 $\log _{10} \mathrm{UFC} / \mathrm{mL}$ to bulk milk. The difference between the two temperatures of transportation was of 4 fold and statistically significant $(\mathrm{p}<0,05)$ by analysis of variance and by $\mathrm{t}$-student for dependent samples.

Key words: milk, temperature of transport, canned milk, bulk milk, mesophilic, coliforms, psicrotrophs. 